\title{
A Perspective Review on Methodologies for Treating Sugar Industry Effluents
}

\author{
Sadaf Sarfraz ${ }^{1 *}$, Ayesha Siddique ${ }^{1}$, Fouzia Qamar' ${ }^{2}$, Shahid Raza ${ }^{3}$ and Abdul Majeed ${ }^{2}$ \\ ${ }^{1}$ Department of Chemistry, Lahore Garrison University, Pakistan \\ ${ }^{2}$ Department of Biology, Lahore Garrison University, Pakistan \\ ${ }^{3}$ Office of Research and Innovative Commercialization (ORIC), Lahore Garrison University, Pakistan
}

Submission: September 03, 2019; Published: September 25, 2019

*Corresponding author: Sadaf Sarfraz, Department of Chemistry, Lahore Garrison University, Lahore, Pakistan

\begin{abstract}
Due to high pollution load, sugar industry is considered as one of the topmost pollutions generating industries affecting our environment. Wastewater from sugar industry bears intricate properties and its treatment is considered as one of the challenging tasks for environmental engineers in terms of its treatment as well as reutilization. The brown color, high temperature, low pH, high COD, high BOD, TDS, odor problems and excessive percentage of dissolved organics and inorganics hallmarks the sugar industrial effluent. This effluent if discharged untreated, poses problems for both marine and terrestrial ecosystems. The cost effective and economical treatment of sugar industrial waste is a challenging task. Therefore, implication of appropriate and cost-effective method to meet the discharge standards is the utterly required need of time. This study gives a brief and concise overview of various techniques employed for treating sugar industrial effluents.
\end{abstract}

Keywords: Sugar industry; Environment pollution; Adsorption; Biological methods; Electro-oxidation, Thermolysis

Abbreviation: AFR: Anaerobic Fixed Bed Reactor; BOD: Biological Oxygen Demand; BSI: British Standard Institutes; BP: British Plastic; COD: Chemical Oxygen Demand

\section{Introduction}

Regardless of the entire water accessibility, only $3 \%$ of fresh water is accessible on earth [1]. Due to extensive industrialization and urbanization, serious opposing challenges in collection, treatment and disposal of industrial effluents have been observed. Unfortunately, due to deficiency of knowledge, financial support and sometimes reluctance to employ wastewater treatment methods; most of the industries discharge their wastes without adopting requisite treatment strategies. These not only cause health problems but also contaminate freshwater resources [2]. Untreated waste elements from industrial sector, agriculture area and municipalities deteriorate the environment segments causing pollution of air, water, land and soil. Above 700 contaminants, both organic and inorganic have been reported in water followed by microbial and industrial activities [3]. Many pollutants among these are hazardous due to their toxicity and carcinogenic nature [4]. This situation is leading to severe health problems and environmental deprivation. In this regard, water conservation policies are ear mark in preservation of freshwater bodies as well as in maintaining water quality standards [5]. World Bank executed stringent rules and protocols to protect the environment from potential hazards caused by industrial discharge. Various parameters describing the quality of water elucidated given by the World Bank is summarized in Table 1.

Table 1: Physico-chemical Properties of Drinking Water [5].

\begin{tabular}{|c|c|}
\hline Parameter & Max. Value (mg/L) \\
\hline pH value & $6-9$ \\
\hline Biological content & -- \\
\hline Chemical content & $150-250$ \\
\hline Total solid content & 50 \\
\hline Oil and grease content & 10 \\
\hline Total nitrogen content & -- \\
\hline Total phosphorus content & -- \\
\hline Temperature & $\leq 3^{\circ} \mathrm{C}$ increase \\
\hline
\end{tabular}

Sugar industry is an agro-based industry and liquidation of its effluents into nearby land-dwelling and marine systems has become the general practice [6]. Throughout the production of sugar enormous quantity of water is used per day, consequently, the industry generates lot of water effluents on regular basis. This wastewater from sugar industry contains large amount of pollutants [7]. These pollutants include not only a large 
number of chemicals being used at different steps during sugar manufacturing process but also includes some quantities of oil and grease generated from the process house [8]. Wastewater from sugar industry when not treated properly also generates nasty odor when discharged into the surroundings. Due to its complex characteristics, treatment of sugar industrial effluent has become an ever-growing challenge [9]. Appropriate treatment methods are needed to meet the rigorous discharge measures for the protection of environment and its surroundings.

Sugar industrial effluents are usually treated by implementing diversed physical, chemical and biological processes [10]. The former includes processes like adsorption, coagulation/ flocculation, electrocoagulation and flotation. Biological methods include aerobic, an-aerobic and membrane assisted methods [11]. Some studies indicate simultaneous use of both aerobic and anaerobic process for the treatment of sugar industrial effluents [12]. The study at hand reveals a contingent approach of various methodologies employed for the removal of pollutants from sugar industries.

\section{Biological Methods}

As the sugar industrial waste comprises a large amount of sugars and volatile fatty acids which can easily be biodegraded by biological methods; therefore, both anaerobic and aerobic treatments have been tremendously employed in treating sugar industrial waste [13].

\section{Aerobic treatment}

Degradation of organic matter in the presence of oxygen is referred to aerobic process. Traditional aerobic methods employed for processing of sugar industrial effluents include usage of activated slime, trickling filters, aerated bayous or combination of these [14]. Effluents from sugar industry can easily be biodegraded excluding the oil and grease contents. The oils and fats cannot be degraded aerobically due to the production of methane during hydrolysis $[15,16]$.

A series of experiments has been conducted by a group of researchers on batch reactor in order to verify the validity of aerobic processes in treating sugar industry wastewater. From the results obtained it was indicated that biodegradation of wastewater in the presence of oxygen offers a promising reduction an agreeable reduction in pollutants [9].

\section{Anaerobic treatment}

Anaerobic process employed for removal of pollutants is the most commonly used method in industries. It has numerous advantages on aerobic processes. One of the most advantageous factors of anaerobic process lies in lesser energy requirement due to methane production resulting in the degradation of organic matters. This consequently causes reduction in sludge production, which in turns effectively lowers down sludge disposal costs [17]. Anaerobic batch reactor, anaerobic fixedbed reactors (AFR), up-flow anaerobic fixed bed (UAFB) reactor, and up flow anaerobic sludge bed reactor (UASB) reactor are generally engaged for anaerobic treatment of sugar industrial wastewater [18].

Literature studies indicate that most of the biological processes applied for treatment of sugar industrial effluents are not feasible owing to huge land space requirement, high principle and functional cost price [19]. Therefore, physicochemical methods are considered economical substitute for the treatment of sugar industry wastewater where conventional biological methods fail to diminish the contaminants [20].

\section{Physico-Chemical Methods}

\section{Adsorption}

Adsorption is considered a primary stage and is ascertained to be useful in the treatment of wastewater by using various adsorbents [21]. Adsorption is defined as accumulation of a specific component at the surface or interface between two phases. Substance or a pollutant that adheres or sticks to the solid surface is known as adsorbate and the solid surface is called adsorbent [22]. Best adsorbents are considered to follow the subsequent characteristics - a substance, with higher surface area, high permeability, inertness and stability to endure thermal, chemical and climatic changes, it should also be cost effective and must have good physicochemical properties [23,24]. Recently advancements in the use of in-expensive adsorbents have led to instant development in this methodology [25].

Presently, adsorption process is being extensively used for the removal of various organic and inorganic pollutants from sugar industry wastewater [26]. In one of the studies M. Sunitha [27] reported that, adsorption is a quick, cost-effective and a promising technique for the elimination of pollutants emerging from different refining and recycling technologies. In this study adsorbents like bentonite, Mgo, activated charcoal, and fly ash were used as adsorbents for sugar industrial effluents [27]. These adsorbents have been reported in $80 \%$ removal of TSS, TDS and oils and grease, along with an effective reduction in BOD, COD, smell and color. The major drawback of adsorption lies in the regeneration of the consumed adsorbent and subsequent treatment of backwash water [28].

\section{Coagulation and flocculation}

Coagulation has been known to be used for effluents treatment since $19^{\text {th }}$ century [29]. Coagulation-flocculation is particularly employed for effective removal of colloidal sized particles. Om Parkash Sahu and his coworkers studied that coagulation is considerably affected by $\mathrm{pH}$ changes and results in a significant removal of colored impurities as well as an efficient reduction in COD [30]. From various studies it is found that for coagulants like ferric chloride, alum, ferrous sulfate and aluminum chloride optimum $\mathrm{pH}$ values ranges from 6-8. The maximum COD and color removals of $82-78 \%$ were achieved through the application of alum as compared to ferrous sulphate resulting in $82-76 \%$ 
COD and color reduction [31]. It was reported that Alum shows $80-86 \%$ of COD and color reduction as compared to aluminum chloride which showed reductions of $75-85.7 \%$ whereas ferrous sulfate gives 76-82\% respectively [32] (Figure 1). Coagulation and flocculation are usually followed by sedimentation, filtration and disinfection. The problems with this treatment process include poor \% recovery, operational issues, arbitrary guidelines and dependency on various operational parameters [33].

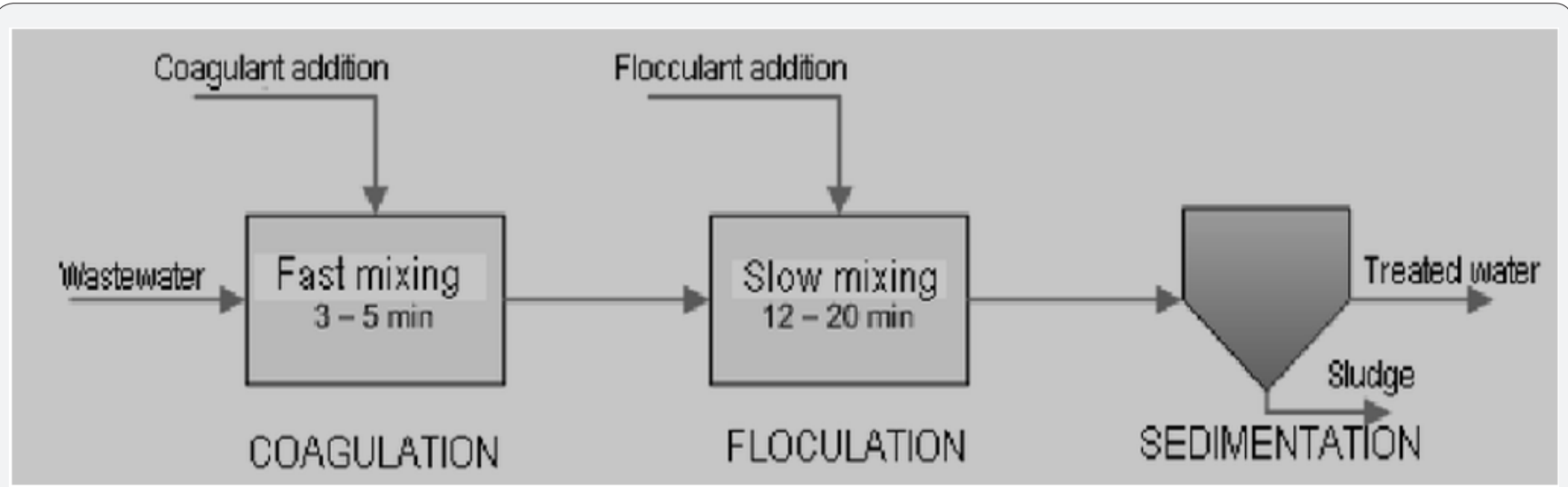

Figure 1: Schematic illustration of effluent treatment using coagulant/flocculants [32].

\section{Electrocoagulation and flotation}

Electrocoagulation is a quicker and an inexpensive methodology. Due to high removal efficiency electrocoagulation and flotation (ECF) are considered to constitute an effective method over other conventional physico-chemical processes [34]. This technology gathers the use of electric current and pollutants that are accumulated without the addition of chemicals or coagulating agents. Application of direct current enables the removal of even minor amounts of pollutants from industrial effluents. Moreover, ECF is a proficient technique to eliminate residues for side products [35]. Different reagents such as aluminium sulfate, ferrous sulfate or ferric chloride have been reported to be employed in electrocoagulation process [36]. However, these chemicals were found to be very expensive and dependent on the volume of water treated.

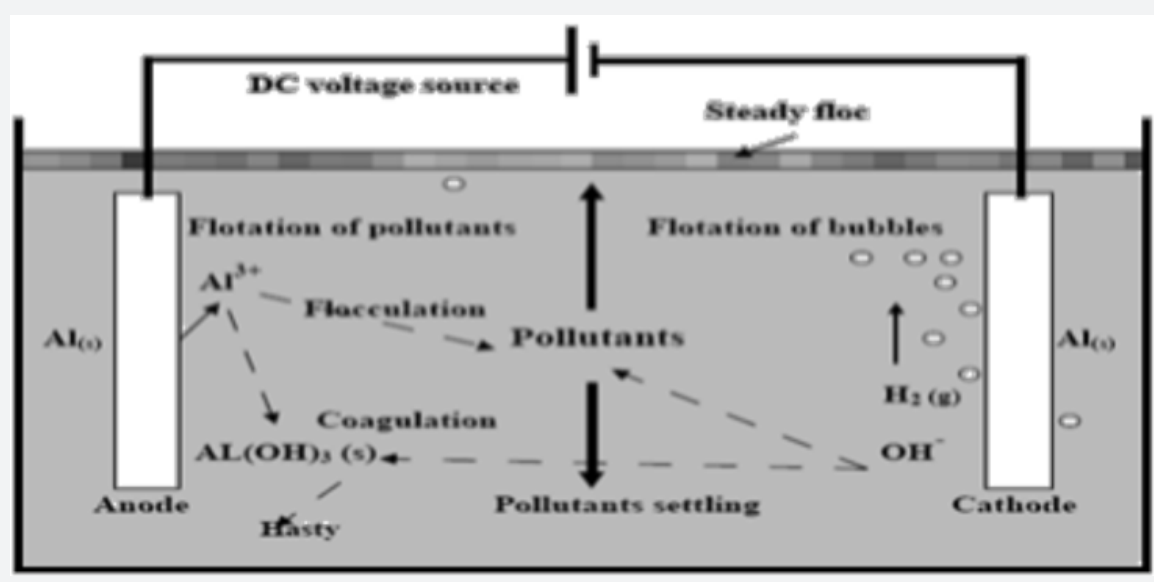

Figure 2: A Schematic illustration of electro-coagulation [37].

The advantage of ECF over other physical processes lies in its capability to reduce the need of chemicals which is due to the use of electrodes which themselves act as coagulating agents [37] (Figure 2). This hereby results in decrease of treatment time of the process [38]. A comparative study of electrocoagulation and chemical coagulation in treating sugar industrial effluent was carried out by Erick Butler and his coworkers. In this study iron and aluminium electrodes were used as electro-coagulants whereas $\mathrm{FeCl} 3$ and $\mathrm{Al} 2\left(\mathrm{SO}_{4}\right) 3.3 \mathrm{H}_{2} \mathrm{O}$ were used as chemical coagulants. In accordance with the primary results achieved, the iron electrodes were found to be more promising in pollutants removal as compared to the aluminum electrodes, despite the fact that use of iron electrodes requires an additional filtration step at the final stage [39].

\section{Thermolysis}

The term "Thermolysis" refers to the thermal treatment of industrial waste. It involves chemical transformation of the 
dissolved organics and inorganics into suspended forms with or without the use of metal compounds at moderate temperature and pressure [40]. Parameters like $\mathrm{pH}$, temperature, autogenous pressure, and catalysts have been found crucial to control the rate of thermolysis process. Thermolysis has been reported to be the best methodology exercised for treating moderate to high strength organic wastes. In a study conducted by P.K. Chaudhari [41] investigated the influence of various parameters such as temperature, $\mathrm{pH}$, catalyst mass loading, and nature of catalysts exerted reduction in COD, BOD and color of the wastewater. It was observed that different catalysts give different \%age removal under different $\mathrm{pH}$ values. Among various catalysts employed in thermolysis process, copper oxide gives maximum efficiency providing $74 \%$ COD and $80 \%$ reduction in color [41].

A comprehensive comparison of various methodologies described above in treating sugar industrial effluent is given in Table 2.

Table 2: A comparative overview of various methodologies.

\begin{tabular}{|c|c|c|c|c|c|c|c|}
\hline \multicolumn{8}{|c|}{ I. Coagulation/Flocculation } \\
\hline Sr. No. & Coagulants Used & pH Value & Dose [mM] & COD Reduction [\%] & Color Reduction [\%] & BOD Reduction [\%] & Ref. \\
\hline \multirow{3}{*}{1} & \multirow{3}{*}{$\mathrm{Fe}_{2}\left(\mathrm{SO}_{4}\right) 3.9 \mathrm{H}_{2} \mathrm{O}$} & $2-6$ & $20-60$ & $36-71$ & $42-74$ & 64 & [36] \\
\hline & & 7 & $20-60$ & 64 & 72 & 70 & [36] \\
\hline & & $8-10$ & 40 & $42-56$ & $68-60$ & - & [36] \\
\hline \multirow{3}{*}{2} & \multirow{3}{*}{$\mathrm{FeCl}_{3}$} & $2-6$ & $20-60$ & $28-62$ & $35-74$ & 70 & {$[6]$} \\
\hline & & 7 & $20-60$ & 69 & 82 & 80 & [32] \\
\hline & & $8-10$ & 40 & $50-58$ & 64 & - & [39] \\
\hline \multirow{3}{*}{3} & \multirow{3}{*}{$\mathrm{AlCl} 3.6 \mathrm{H}_{2} \mathrm{O}$} & $2-6$ & $20-60$ & $29-62$ & $30-66$ & 60 & [15] \\
\hline & & 7 & $20-60$ & 69.3 & 76 & - & [15] \\
\hline & & $8-10$ & 60 & $55-73$ & $71-83$ & 74 & [15] \\
\hline \multirow{3}{*}{4} & \multirow{3}{*}{ Alum } & $2-8$ & $40-60$ & $23-64$ & 24 & 24 & [39] \\
\hline & & 7 & -- & 74.5 & 74 & - & [39] \\
\hline & & $8-10$ & -- & $60-67$ & $59-66$ & - & [39] \\
\hline \multicolumn{8}{|c|}{ II. Thermolysis } \\
\hline Sr. No. & Catalyst used & pH value & Dose $\left[\mathrm{g} / \mathrm{dm}^{3}\right]$ & COD reduction [\%] & Color reduction [\%] & BOD reduction [\%] & Ref. \\
\hline 1 & Copper oxide & $2-10$ & 4 & 74 & 80 & 80 & [40] \\
\hline \multicolumn{8}{|c|}{ III. Adsorption } \\
\hline Sr. No. & Adsorbent used & pH value & Dose [mg] & COD reduction [\%] & Color reduction [\%] & BOD reduction [\%] & Ref. \\
\hline 1 & $\begin{array}{l}\text { Activated } \\
\text { charcoal }\end{array}$ & & - & 80 & 80 & 80 & [21] \\
\hline 2 & Bentonite & 4 & 50.7 & 80 & 80 & 80 & [21] \\
\hline 3 & Lignite & & - & 80 & 80 & 80 & [21] \\
\hline 4 & Fly ash & & - & 80 & 80 & 80 & [7] \\
\hline 5 & Bagasse & & - & 80 & 80 & 80 & {$[4]$} \\
\hline 6 & kaolin & & 500 & 79 & - & - & [7] \\
\hline 7 & $\begin{array}{l}\text { Tamarind nut } \\
\text { carbon }\end{array}$ & & 600 & 74 & - & - & [12] \\
\hline 8 & Dates nut carbon & & 600 & 73 & - & - & [12] \\
\hline \multicolumn{8}{|c|}{ IV. Electrocoagulation } \\
\hline Sr. No. & Electrode Used & pH Value & Time [hrs] & Voltage & COD Reduction [\%] & $\begin{array}{c}\text { Turbidity } \\
\text { Reduction [\%] }\end{array}$ & Ref. \\
\hline \multirow{3}{*}{1} & \multirow{3}{*}{ Iron Electrodes } & 5 & 4 & 10-Aug & $67-82$ & $70-84$ & [34] \\
\hline & & 6 & 4 & 10-Aug & $70-84$ & 78-93 & [7] \\
\hline & & 7 & 4 & 10-Aug & $72-89$ & $72-89$ & {$[34]$} \\
\hline 2 & $\begin{array}{l}\text { Aluminium } \\
\text { electrodes }\end{array}$ & 6.93 & 2 & -- & $60.8-63.5$ & 87.5-98 & [26] \\
\hline
\end{tabular}




\section{International Journal of Environmental Sciences \& Natural Resources}

\begin{tabular}{|c|c|c|c|c|c|c|}
\hline \multicolumn{7}{|c|}{ V. Biological Treatment Process } \\
\hline Sr. No. & Type of Waste & $\begin{array}{l}\text { Type of } \\
\text { Reactor }\end{array}$ & $\begin{array}{c}\text { Methane Yield } \\
{[\mathrm{mL} / \mathrm{g}]}\end{array}$ & COD Reduction [\%] & $\begin{array}{c}\text { Hydraulic } \\
\text { Retention Time }\end{array}$ & Ref. \\
\hline 1 & BSI and BP & $\begin{array}{c}\text { Anaerobic } \\
\text { batch reactor }\end{array}$ & $236-322$ & $64-87$ & - & [15] \\
\hline 2 & CSI & $\begin{array}{l}\text { Aerated film } \\
\text { reactor }\end{array}$ & - & $<90$ & $4(\mathrm{~h})$ & [9] \\
\hline 3 & SR & $\begin{array}{l}\text { Rotating } \\
\text { biological } \\
\text { reactor }\end{array}$ & - & 48 & - & [15] \\
\hline 4 & CSI & $\begin{array}{c}\text { Aerated fix } \\
\text { film biological } \\
\text { system }\end{array}$ & - & $74-68$ & $2-8 \mathrm{~h}$ & [9] \\
\hline 5 & BSI & UAFB & - & $>90$ & $20 \mathrm{~h}$ & [1] \\
\hline
\end{tabular}

\section{Conclusion}

The results of this study have shown the applicability of different strategies to reduce the detrimental effects of various pollutants from sugar industry. To comply with the discharge standards set by the Agencies responsible for environmental compliance, it is important that industries should take appropriate measures for catering these issues that have compelled sugar industry to occupy position as "Red category" industry. Comparative account of various discussed processes/ methods actually provides an insight into the best opted alternates to address the challenges imposed by the hazardous wastes. In addition to all possible approaches to minimize the pollutant problems discussed here, more research is required to address existing loopholes and gaps in order to provide a comprehensive and cost-effective solution to revise and establish the status of sugar industries as zero discharge units.

\section{References}

1. Awasare SD, Bhosale HU, Chavan NP (2015) Effluent Treatment Plant of Sugar Wastewater-A Review. Intl J of Sci Res in Sci and Technol 1(5): 102-107.

2. Kumar DS, Srikantaswamy S (2015) Evaluation of effluent quality of a sugar industry by using physico-chemical parameters. Intl J Adv Res Eng Appl Sci 4(1): 16-25.

3. Tanksali A (2013) Treatment of sugar industry wastewater by upflow anaerobic sludge blanket reactor. Intl J Chem Tech Res 5(3): 12461253.

4. Yang M (2011) A current global view of environmental and occupational cancers. J Environ Sci Health C Environ Carcinog Ecotoxicol Rev 29(3): 223-249.

5. Prevention P (1998) Handbook, World Bank Group. Washington, DC.

6. Kushwaha JP, Chandra Srivastava V, Mall ID (2010) Treatment of dairy wastewater by inorganic coagulants: Parametric and disposal studies. Water Res 44(20): 5867-5874.

7. Ansari AK (2006) Sugar industry effluent-characteristics and chemical analysis. J Appl Emerg Sci 1(2): 152-157.

8. Saleem M, Bukhari AA, Akram MN (2011) Electrocoagulation for the treatment of wastewater for reuse in irrigation and plantation. J Basic \& Appl Sci 7(1): 11-20.
9. Kushwaha JP (2015) A review on sugar industry wastewater: sources, treatment technologies, and reuse. Desalination and water treatment 53(2): 309-318.

10. Gupta VK, Jain CK, Ali I, Chandra S, Agarwal S (2002) Removal of lindane and malathion from wastewater using bagasse fly ash-a sugar industry waste. Water Res 36(10): 2483-2490.

11. Rais M, Sheoran A (2015) Treatment of sugarcane industry effluents: science \& technology issues. Intl J Eng Res and Appl 5(1): 11-19.

12. Nähle C (1990) Purification of waste water in sugar factories-anaerobic and aerobic treatment, $\mathrm{N}$-elimination. Zuckerindustrie 115(1): 27-32.

13. Nacheva PM, Chávez GM, Chacón JM, Chuil AC (2009) Treatment of cane sugar mill wastewater in an upflow anaerobic sludge bed reactor. Water Sci Technol 60(5): 1347-1352.

14. Carta-Escobar F, Marin JP, Mateos PA, Guzman FR, Barrantes MMD, et al. (2004) Aerobic purification of dairy wastewater in continuous regime: Part I: Analysis of the biodegradation process in two reactor configurations. Biochem Eng J 21(2): 183-191.

15. Kushwaha JP, Srivastava VC, Mall ID (2011) An overview of various technologies for the treatment of dairy wastewaters. Crit Rev Food Sci Nutr 51(5): 442-452.

16. Hanaki K, Matsuo T, Nagase M (1981) Mechanism of inhibition caused by long-chain fatty acids in anaerobic digestion process. Biotechnol and Bioeng 23(7): 1591-1610.

17. Khan M, Kalsoom U, Mahmood T, Riaz M, Khan AR (2003) Characterization and treatment of industrial effluent from sugar industry. J Chem Soc Pak 25(3): 242-247.

18. Ramjeawon T, Baguant J (1995) Evaluation of critical BOD loadings from Mauritian sugar factories to streams and standards setting. J Env Manag 45(2): 163-176

19. Alkaya E, Demirer GN (2011) Anaerobic-fed and sequencing-batch treatment of sugar-beet processing wastes: a comparative study. Water Environ Res 83(3): 247-255.

20. Srihari V, Das A (2004) Reduction of chemical oxygen demand of sugar industry effluents using natural clays as adsorbents. Res J Chem Environ 8(2).

21. Sunitha M, Rafeeq MA (2009) Sugar industry wastewater treatment using adsorption. J Ind Pollut Control 25(2): 109-112.

22. Dakiky M, Khamis M, Manassra A, Mereb M (2002) Selective adsorption of chromium (VI) in industrial wastewater using low-cost abundantly available adsorbents. Adv Env Res 6(4): 533-540. 
23. Namasivayam C, Kavitha D (2002) Removal of Congo Red from water by adsorption onto activated carbon prepared from coir pith, an agricultural solid waste. Dyes and Pigments 54(1): 47-58.

24. Hasar H (2003) Adsorption of nickel (II) from aqueous solution onto activated carbon prepared from almond husk. J Hazard Mater 97(1-3): 49-57.

25. Bromley-Challenor KCA, Knapp JS, Zhang Z, Gray NCC, Hetheridge MJ, et al. (2000) Decolorization of an azo dye by unacclimated activated sludge under anaerobic conditions. Water Res 34(18): 4410-4418.

26. Yu Y, Zhuang YY, Wang ZH (2001) Adsorption of water-soluble dye onto functionalized resin. J Coll Inter Sci 242(2): 288-293.

27. Driessel BV, Christov L (2002) Adsorption of colour from a bleach plant effluent using biomass and cell wall fractions from Rhizomucor pusillus. J Chem Technol \& Biotechnol: Intl Res in Process, Environmental \& Clean Technol 77(2): 155-158.

28. Anjaneyulu Y, Chary NS, Raj DSS (2005) Decolourization of industrial effluents-available methods and emerging technologies-a review. Rev Environ Sci Bio 4(4): 245-273.

29. Güven G, Perendeci A, Tanyolac A (2009) Electrochemical treatment of simulated beet sugar factory wastewater. J Chem Eng 151(1-3): 149-159.

30. Tchamango S, Njiki CPN, Ngameni E, Hadjiev D, Darchen A (2010) Treatment of dairy effluents by electrocoagulation using aluminium electrodes. Sci Total Environ 408(4): 947-952.

31. Shammas NK, Pouet MF, Grasmick A (2010) Wastewater treatment by electrocoagulation-flotation. Flotation Technol, pp. 199-220.

32. Bukhari AA (2008) Investigation of the electro-coagulation treatment process for the removal of total suspended solids and turbidity from municipal wastewater. Bioresour Technol 99(5): 914-921.
33. Holt PK, Barton GW, Wark M, Mitchell CA (2002) A quantitative comparison between chemical dosing and electrocoagulation. Colloids and Surfaces A: Physicochemical and Engineering Aspects 211(2-3): 233-248.

34. Cañizares P, Jiménez C, Martínez F, Rodrigo MA, Sáez C (2009) The $\mathrm{pH}$ as a key parameter in the choice between coagulation and electrocoagulation for the treatment of wastewaters. J Hazard Mater 163(1): 158-164.

35. Ben Sasson M, Adin A (2010) Fouling mitigation by iron-based electroflocculation in microfiltration: Mechanisms and energy minimization. Water Res 44(13): 3973-3981.

36. Chen G (2004) Electrochemical technologies in wastewater treatment. Sep Purif Technol 38(1): 11-41

37. Can O, Kobya M, Demirbas E, Bayamoglu M (2006) Treatment of the textile wastewater by combined electrocoagulation. Chemosphere 62(2): 181-187.

38. Hinkova A, Bubnik Z, Kadlec P, Pridal J (2002) Potentials of separation membranes in the sugar industry. Sep Purif Technol 26(1): 101-110.

39. Verma S, Prasad B, Mishra IM (2011) Thermochemical treatment (thermolysis) of petrochemical wastewater: COD removal mechanism and floc formation. J Ind Eng Chem 50(9): 5352-5359.

40. Chaudhari PK, Mishra I, Chand S (2008) Effluent treatment for alcohol distillery: Catalytic thermal pretreatment (catalytic thermolysis) with energy recovery. Chem Eng J 136(1): 14-24.

41. Essadki A, Bennajah M, Gourich B, Vial CH, Azzi M, et al. (2008) Electrocoagulation/electroflotation in an external-loop airlift reactor-Application to the decolorization of textile dye wastewater: A case study. Chem Eng Process 47(8): 1211-1223.

Your next submission with Juniper Publishers will reach you the below assets

- Quality Editorial service

- Swift Peer Review

- Reprints availability

- E-prints Service

- Manuscript Podcast for convenient understanding

- Global attainment for your research

- Manuscript accessibility in different formats

( Pdf, E-pub, Full Text, Audio)

- Unceasing customer service

Track the below URL for one-step submission https://juniperpublishers.com/online-submission.php 